[J.Jpn.Soc. Starch Sci., Vol.30, No.4, p. 342 347(1983)]

\title{
Starch and Alcohol Fermentation of Viviparous Buds of Mangroves
}

\author{
Takehiko Yamamoto, Kazuo Uenakai and Jiro SUgi* \\ Faculty of Science, Osaka City University \\ (Sumiyoshi-ku, Osaka 558, Japan) \\ *Nodai Research Institute, Tokyo University of Agriculture \\ (Setagaya-ku, Tokyo 156, Japan)
}

(Received August 11, 1983)

\begin{abstract}
The viviparous buds of mangroves were found to contain starch in amounts up to $28 \%$ on a dry basis. The starch granules existed separately, being inserted between cellulosic fibers of the tissue. The starch granules were ellipsoidal or oval of $c a$. $10-8 \times 5-3 \mu \mathrm{m}$, depending on the kind of mangroves.

The viviparous buds were examined for alcohol fermentation after steeping in hot water and crushing mechanically. Glucoamylase and pectic enzymes were added to the mash for saccharification of starch and maceration of the crushed tissue, respectively. The starch in the viviparous buds were fermented to alcohol, but a satisfactory fermentation efficiency was not obtained. From the facts that the tissue of viviparous buds is tough to treat and contains tannic substance, the processing for alcohol fermentation is discussed.
\end{abstract}

Mangroves, an embryonic plant constituting the major forest of the plant community in tidal swamp area of South East Asia, bear a great number of viviparous buds annually. The size of the buds varies from 25 to $60 \mathrm{~cm}$ in length and, from 15 to $100 \mathrm{~g}$ in weight depending on the kind of mangroves. Their tissues are generally tough and consist of cellulosic, hemicellulosic and pectic substances, and contain sodium and calcium salts as the major inorganic substance. They also contain starch and tannic substance. Application of this tannic substance has been established to some extent. However, most of the viviparous buds lose their lives in vein by being carried away with sea water or by falling down in so unfortunate way on the ground as not to be able to root for growth. It happens in some circumstances that the beach of mangrove flora is covered with dead viviparous buds. Therefore, it may be necessary to manage the viviparous buds of mangrove trees to keep them as a sound forest to be able to play the important role of protecting the sea shore from erosion and to maintain various living organisms in the surrounding sea water.

The present study was thus attempted to find a clue for development of utilization of viviparous buds of mangroves. As a preliminary report, this paper describes isolation and some properties of starch in mangrove viviparous buds and feasibility of application of the buds for alcohol fermentation.

\section{MATERIALS AND METHODS}

1. Viviparous buds of mangroves examined. Ceriops tagal, Rhizophora apicurata and Rhizophora mucronata were collected from marsh lands in Phuket, Southern Thailand in March, 1982. The viviparous buds of $R$. mucronata obtained in Iriomote Island, Okinawa Pref. of Japan in October were also examined.

2. Detection and quantitative determination of starch. The starch in tissue of viviparous bud was detected by staining the tissue section with iodine-potassium iodide solution. For 
quantitative determination of starch, viviparous buds were grated using a grater at kitchen. The mash obtained was suspended in 50 or 100 weights of water and the suspension was boiled for $30 \mathrm{~min}$. The suspension was cooled to $50^{\circ} \mathrm{C}$, the $\mathrm{pH}$ was adjusted at 5.0 , and a commercial preparation of glucoamylase was added to the suspension in a proportion of $2.0 \mathrm{mg}$ per $1 \mathrm{~g}$ of the buds on dry basis. After incubation for $16 \mathrm{hr}$ under few drops of toluene, the suspension was centrifuged and the supernatant was subjected to determination of reducing sugar as glucose by the method of Shaffer-Somogyi. ${ }^{1)}$ The control run was the suspension incubated with the enzyme previously inactivated by heating in boiling water for $20 \mathrm{~min}$, and the reducing sugar as glucose estimated with this suspension was subtracted from the reducing sugars observed for the incubation mixture with active glucoamylase. The starch content was estimated by multiplying the factor, $162 / 180$, to the glucose value thus obtained.

The reducing sugar produced by hydrolyzing the grated viviparous buds with 100 volumes of $1.0 \mathrm{~N}$ hydrochloric acid at $100^{\circ} \mathrm{C}$ for $2 \mathrm{hr}$ was also estimated. The difference between the value estimated as glucose by this method and that of glucose determined by using glucoamylase was tentatively expressed as hemicellulosic polysaccharides.

3. Isolation of starch. The isolation of starch from the viviparous buds was done as follows: Five hundred grams each of the buds were sliced and suspended in 5 weights of water. The suspension was subjected to homogenization by a Waring blender at a high speed for $1 \mathrm{~min}$. The homogenate obtained was transferred to a big glass cylinder and tap water was allowed to flow through a glass tube to the bottom to wash out light specific gravity materials leaving starch as precipitate.

4. Fermentability for alcohol of viviparous buds. The buds were cut down into rough pieces and kept in water heated at $70^{\circ} \mathrm{C}$ for $30 \mathrm{~min}$ to inactivate polyphenol oxidase. Then, the bud pieces were taken out and cooled to room temperature. An equal weight of water was added to the pieces and homogenized in a Waring blender at a high speed for $2 \mathrm{~min}$. Commercial preparations of pectic enzymes

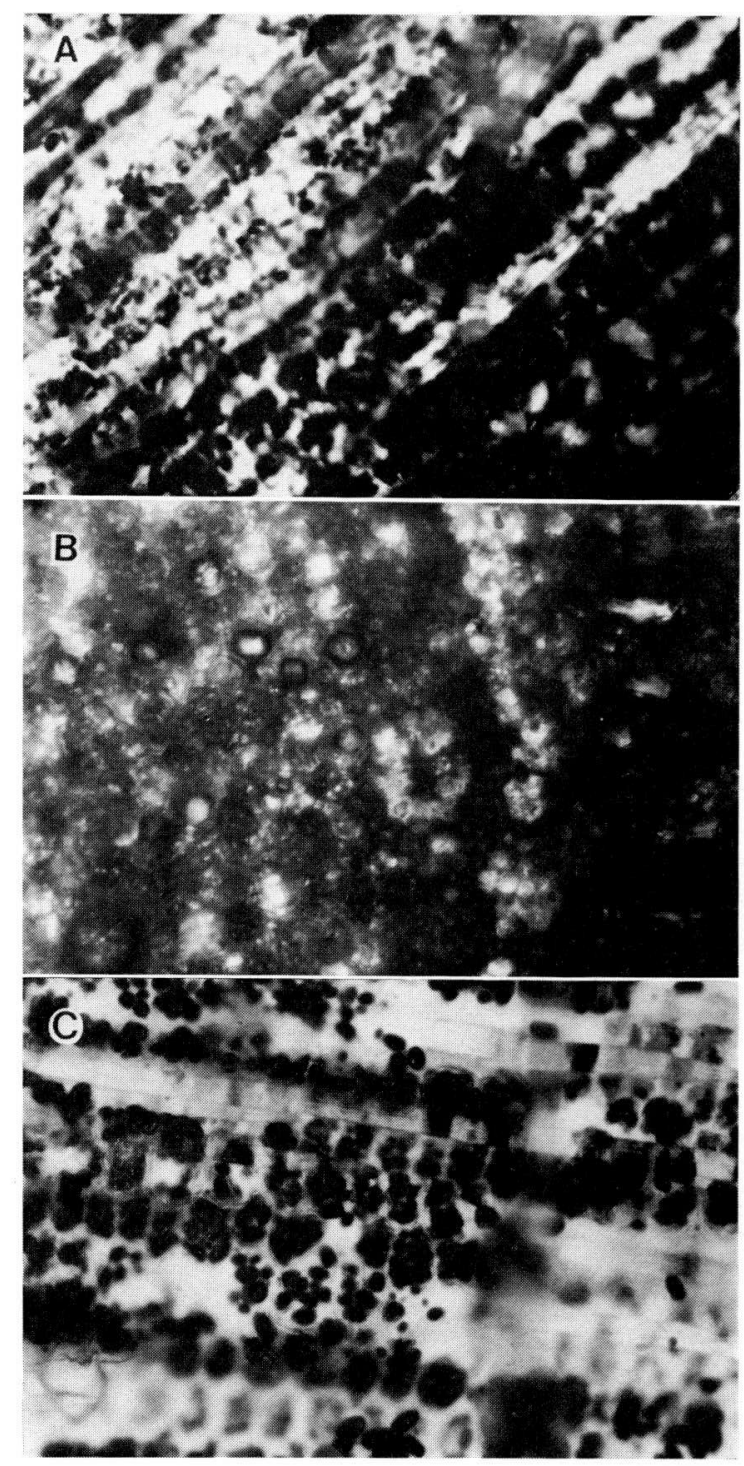

Fig. 1. Starch granules in viviparous bud of mangroves.

Stained with iodine; magnif., ca. 200.

A, Rhizophora mucronata (sectioned tangentially);

B, Rhizophora apiculata (sectioned vertically);

C, Ceriops tagel (sectioned tangentially).

$(0.25 \mathrm{~g})$, glucoamylase $(0.25 \mathrm{~g})$ and dry yeast $(2.5 \mathrm{~g})$ were added to $500 \mathrm{~g}$ of the homogenate and incubated in a modified Meissel bottle at $28^{\circ} \mathrm{C}$. The degree of production of alcohol was tentatively expressed by weight loss of the incubation mixture due to evolution of carbon dioxide. 


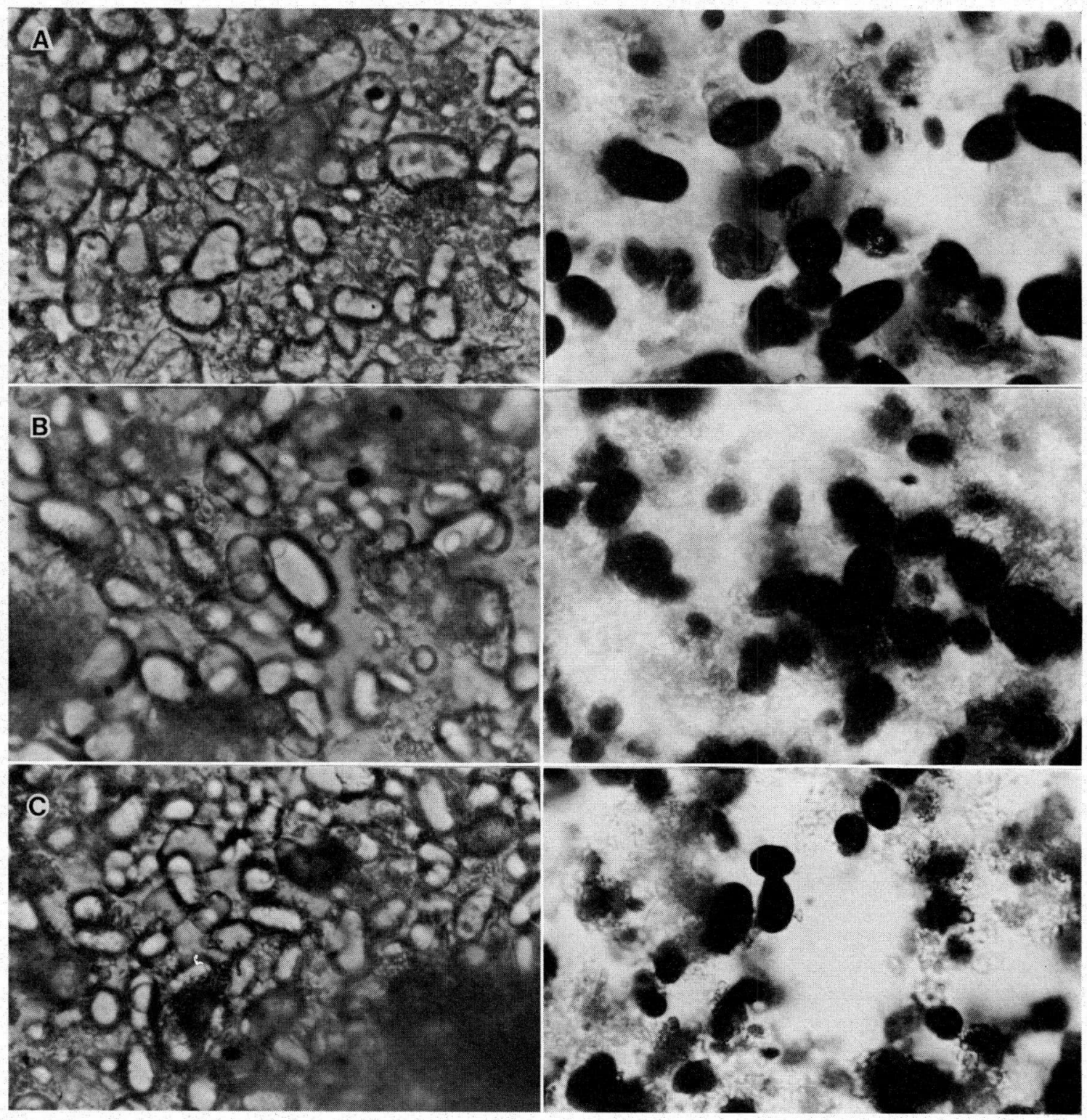

Fig. 2. Photomicrographs of starch granules isolated from mangrove viviparous buds. Left, without staining; right, after staining with iodine; magnif., ca. 800. A, Rhizophora mucronata; B, Rhizophora apiculata; C, Ceriops tagal.

5. Enzyme preparations used. Glucoamylase was a preparation from Rhizopus niveus. The activity was 6,000 units per g preparation (One unit of the enzyme produced $10 \mathrm{mg}$ of glucose in $30 \mathrm{~min}$ at $40^{\circ} \mathrm{C}$ and at $\mathrm{pH} 5.0$ ). A pectic enzyme preparation ${ }^{2}$. obtained from Aspergillus niger had the activity of 6,000 units as pectin depolymerase per $\mathrm{g}$ preparation (One unit of pectin depolymerase activity was defined as the enzyme amount that reduced the viscosity of $1.0 \%$ citrus pectin of total $10 \mathrm{ml}$ to a half in $10 \mathrm{~min}$ at $\mathrm{pH} 4.0$ and at $40^{\circ} \mathrm{C}$ ). Both enzyme preparations were purchased from Hankyu Kyoei Co. Ltd., Osaka, Japan. The dry yeast used was for bread making which was manufactured by Oriental Yeast Co. Ltd., Tokyo, Japan. 
Table 1. Starch granules in viviparous buds of several mangroves.

\begin{tabular}{|c|c|c|c|}
\hline Mangrove & & Shape & Size $(\mu \mathrm{m})$ \\
\hline $\begin{array}{c}\text { Rhizophora mucronata } \\
\text { " }\end{array}$ & $\left.\begin{array}{l}\text { Thailand } \\
\text { Okinawa, Japan }\end{array}\right\}$ & ellipsoidal & $8-5 \times 4-2$ \\
\hline Rhizophora apiculata & & round-oval & $10-5 \times 5-2.5$ \\
\hline Ceriops tagal & & round-oval & $8-5 \times 5-3$ \\
\hline
\end{tabular}

Table 2. Contents of starch and hemicellulosic polysaccharides of viviparous buds of mangroves.

\begin{tabular}{|c|c|c|c|}
\hline & \multicolumn{3}{|c|}{ Species } \\
\hline & $\begin{array}{l}\text { Rhizophora } \\
\text { mucronata }\end{array}$ & $\begin{array}{l}\text { Rhizophora } \\
\text { apiculata }\end{array}$ & Ceriops tagal \\
\hline Moisture $^{\mathrm{a}}(\%)$ & 50.5 & 47.1 & 62.9 \\
\hline $\operatorname{Starch}^{\mathbf{b}}(\%)$ & 13.6 & 13.9 & 6.87 \\
\hline Hemicellulosic polysaccharides ${ }^{c}(\%)$ & 6.37 & 9.07 & 5.77 \\
\hline $\begin{array}{l}\text { a Determined with a Kett infrared ra } \\
\text { b Starch content }=\text { (glucose produced } \\
\text { c Hemicellulosic polysaccharides }=\text { (to } \\
\quad \text { - (glucose produced by incubati }\end{array}$ & $\begin{array}{l}\text { ture analyzer. } \\
\text { abation with glucoa } \\
\text { ar content after hyd } \\
\text { glucoamylase } \times \frac{16}{18}\end{array}$ & $\begin{array}{l}\text { ylase) } \times \frac{162}{180} \\
\text { olysis with } 1 \mathrm{~N} \mathrm{HC} \\
\text {. }\end{array}$ & $100^{\circ} \mathrm{C}$ for $2 \mathrm{hr}$ ) \\
\hline
\end{tabular}

\section{RESULTS}

\section{Starch in viviparous buds}

The results of staining of the viviparous bud section with iodine-potassium iodide are shown in Fig. 1, where the starch are seen as black spots. Figure 1 indicates that no special loci for starch granules to assemble are there. However, the starch granules mainly existed as a scrumbled state like a bunch of grape and relatively uniformly distributed among fibrovascular bundles in viviparous bud.

The photomicrographs of starch granules isolated from the viviparous buds are shown in Fig. 2. The shape and size of the starch granules are summarized in Table 1 . They were generally regular or irregular oval or ellipsoidal form resembling arrowroot starch. No cracks nor stripes as those found on corn starch or potato starch granules were observed. Their size varied to a considerable extent, depending on the kind of mangrove.

Upon gelatinization in boiling water, the starch granules were found to be hydrolyzed by glucoamylase with nearly the theoretical yield of glucose.

\section{Starch content of viviparous buds}

As shown in Table 2, the starch content of fresh viviparous buds amounted to about 14\% for R. mucronata and R. apiculata. Therefore, the starch content of the former bud is estimated to be $28 \%$ on a dry basis of the sample. As to the content of hemicellulosic polysaccharides, $R$. apiculata was greater than other two mangroves. The other main solid materials were cellulose and inorganic substance.

\section{Alcohol fermentation of viviparous buds}

The results of alcohol fermentation performed by above method are shown in Fig. 3. The amount of carbon dioxide evolved was greatest with the fermented mash of R.mucronata viviparous buds. It is interesting that although the starch content of the buds of C.tagal was nearly a half of those of other two viviparous buds, the degree of carbon dioxide evolution was almost similar to that of $R$. mucronata. Nevertheless, the fermentation efficiency of C. tagal buds was only $60 \%$. 


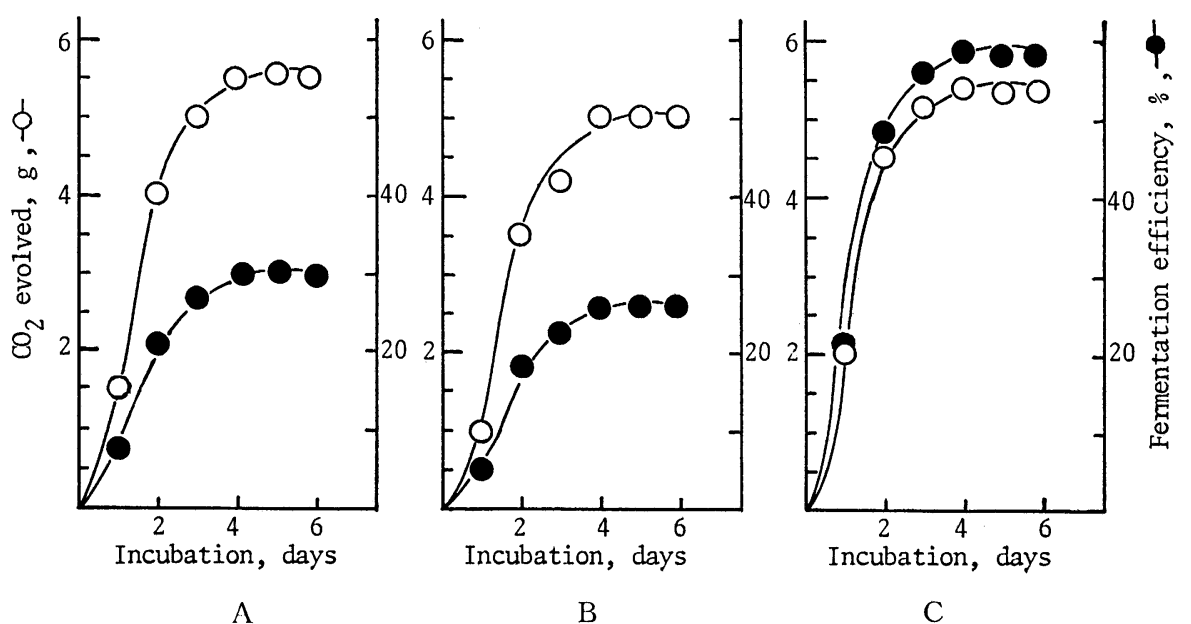

Fig. 3. Alcohol fermentation of viviparous buds.

$250 \mathrm{~g}$ grated bud and $250 \mathrm{~g}$ water.

Fermentation efficiency, $\%=\mathrm{CO}_{2}$ evolved, $\mathrm{g} /\left(\right.$ starch contained, $\left.\mathrm{g} \times \frac{180}{162} \times \frac{88}{180}\right)$.

A, Rhizophora mucronata; B, Rhizophora apiculata; C, Ceriops tagal.

\section{DISCUSSION}

When gelatinized, the granules isolated as starch from the viviparous buds were hydrolyzed by glucoamylase into glucose almost completely. Therefore, the granules were considered to be true starch. The viviparous buds of mangroves examined, however, seem to be a little too small in the starch content to be worth for calling the bud as a starchy organ.

The viviparous bud of $R$. mucronata collected in Okinawa, Japan, was fairly small as compared with that produced in Thailand. But no significant difference in the starch content and fermentability under the conditions were observed between the two viviparous buds. More research will of course be necessary to find the mangroves bearing viviparous bud of higher starch contents than those described above. Also, there may be the possibility to increase the starch content of the bud by breeding.

For alcohol fermentation, the viviparous buds were heated at $70^{\circ} \mathrm{C}$. This was to inactivate polyphenol oxidase, otherwise the mash was colored in deep dark which decreased the activity of glucoamylase. Heating the buds at temperatures than the above value did not necessarily result in more favorable alcohol fermentation.

However, the fermentation efficiency of the viviparous buds was unreasonably low. This result may be partly due to the mode of existence of starch granule in the tissue of viviparous buds. The existence of tannic substance may be another reason. When the bud slices were boiled with $0.1 \mathrm{~N}$ sodium hydroxide for $10 \mathrm{~min}$ and then, neutralized, the alcohol fermentation of the mixture was extremely delayed and the fermentation efficiency was far less than those in the present paper.

The content of cellulosic substance of the viviparous buds used was about 15\% when examined according to the method of Ost and Wilkening. ${ }^{3)} \quad$ It was interesting that cellulosic substance was readily separated by pressing the fermented mash and that the beer thus obtained from $500 \mathrm{~g}$ mash $(250 \mathrm{~g}$ fresh bud and $250 \mathrm{~g}$ water) amounted $300-330 \mathrm{ml}$. The alcohol concentration of the beer from $R$.mucronata viviparous buds after fermentation for 5 days was $2.0 \%(\mathrm{v} / \mathrm{v})$. If all the starch existed was completely fermented, the alcohol concentration would be increased two or three fold. For improving the alcohol fermentation of viviparous buds, further experiments under various condi- 
tions will be necessary. The experiment to make clear the reason of difference in the alcohol fermentation efficiency between the viviparous buds of $R$.apiculata and C.tagal may lead to finding a clue far improvement of fermentation efficiency of the bud.

The cellulosic fiber isolated after alcoholic fermentation of the viviparous buds is under study to apply for methane fermentation which will be published elsewhere.

\section{REFERENCES}

1) P. A. Shaffer and M. Somogyi: J. Biol.Chem., 100, 695 (1933).

2) O. Svendsby, K. KaKUTANI, Y. Matsumura, M. IIzUKA and T. YAMAMOTO: J. Ferment. Technol., 59, 485 (1981).

3) Von H. Ost und L. Wilkening: Chem. Ztg., 34, 461 (1910).

$$
\begin{gathered}
\text { マングローブ胎生芽の澱粉と } \\
\text { アルコール発酵について }
\end{gathered}
$$

山本武彦・上中居和男 · 杉 二郎*

大阪市立大学理学部

（558 大阪市住吉区杉本町）

*東京農業大学総合研究所

（156 東京都世田谷区桜ヶ 丘）

マングローブ胎生芽（タイ国産を主として使用）には 乾量ベースで $28 \%$ も及ぶ澱粉が含まれることがわかっ た。澱粉粒は組織繊維間にはさまれながら散在し，形は 卵型ないし棈球型で長軸が $10 \sim 8 \mu \mathrm{m}$ ，短径が $5 \sim 3 \mu \mathrm{m}$ であった。

胎生芽を温水に浸し，次いで機械的に砕いたのち等量 の水を加光，それに組織溶解のため，ペクチン分解酵素， 澱粉糖化のためグルコアミラーゼ，また発醏のため酵博 を加えアルコール発醅陚験を行った．分離した澱粉はグ ルコアミラーゼで容易に分解されたが，アルコール発醋 試験の結果は必ずしも満足すべきものではなかった。 こ れについて種々の考察を行い，発酵条件に工去を要する ことを指摘した。 